\title{
The Mirage of Immigration Reform: The Devastating Consequences of Obama's Immigration Policy
}

\author{
Marcia Zug*
}

\section{INTRODUCTION}

In the summer of 2014, tens of thousands of Central American women and children arrived at the United States border. ${ }^{1}$ The numbers were unprecedented and their arrival was quickly characterized as a crisis. $^{2}$ However, many immigrants' rights activists also saw it as an opportunity. ${ }^{3}$ They hoped the border crisis would force the government to pass sweeping immigration reform. It did. Unfortunately, many immigrants would have been better off without these changes.

On November 20, 2014, President Obama announced that he would take executive action to protect millions of undocumented immigrants from deportation. ${ }^{4}$ As a result of this decision, certain groups of immigrants became eligible for deferred action. Those who qualify are

\footnotetext{
* Associate Professor of Law at the University of South Carolina. I would like to thank the Kansas Law Review for the wonderful Immigration Law Symposium that led to this article.

1. U.S. Immigration Crisis as Tens of Thousands of Children Flee Central American Violence Without Parents, EuRONEWs (Feb. 7, 2014, 5:27 PM), http://www.euronews.com/2014/07/02/usimmigration-crisis-as-tens-of-thousands-of-children-flee-central-american-/.

2. Aviva Chomsky, The United States' Continuing Border Crisis: The Real Story Behind The "Invasion" of Children, TRUTHOUT (Aug 25, 2014, 11:13 AM), http://truth-out.org/news/item/2 5778-the-united-states-continuing-border-crisis-the-real-story-behind-the-invasion-of-the-children (discussing the characterization of Central American children crossing the U.S.-Mexican border as a "crisis").

3. See, e.g., Scott Martelle, 'An Urgent Humanitarian Situation' at the U.S.-Mexico Border, L.A. TimeS, June 2, 2014, http://touch.latimes.com/\#section/-1/article/p2p-80381227/ (noting that after the surge, "immigration advocates have been lobbying the government to make the issue of unaccompanied minors a high priority."); see also, David Nakamura, Obama Readies Executive Action on Immigration, THE WASHINGTON POST (Aug. 1, 2014), http://www.washingtonpost.com/ politics/obama-readies-executive-action-to-legalize-millions-of-undocumented-immigrants/ 2014/08/01/222ae2e8-18f8-11e4-85b6-c1451e622637_story.html (quoting Frank Sharry, executive director of America's Voice, as predicting that the border surge would give the President the "space for him to go big on administrative action.").

4. President Barack Obama, Remarks in Address to the Nation on Immigration (Nov. 20, 2014), available at http://www.whitehouse.gov/the-press-office/2014/11/20/remarks-presidentaddress-nation-immigration.
} 
protected from deportation for three years, ${ }^{5}$ eligible for a social security number and given the right to work. $^{6}$ For these immigrants, the President's announcement was life changing, ${ }^{7}$ but not all undocumented immigrants qualify. In fact, only two groups of immigrants are eligible for Obama's executive action. ${ }^{8}$ The first are the undocumented parents of United States citizens or legal permanent residents who have been in the United States since January 1, 2010. The second are undocumented children who arrived in the United States before the age of sixteen and have remained in the United States since January 1, 2010. ${ }^{9}$ Conspicuously absent from this list are the thousands of women and children who were part of this summer's immigration surge. As a result, Obama's executive action is something of a Faustian bargain. It enlarges the protections and benefits available to older undocumented arrivals, but it also sanctions the increasingly harsh treatment of more recent entrants.

The President appears to believe that these punitive immigration policies are necessary to prevent expansion of Deferred Action for Childhood Arrival (DACA) from incentivizing additional undocumented immigration. However, it is not at all clear that the connection between DACA and undocumented immigration actually exists. ${ }^{10}$ Moreover,

5. See Michael Olega, Obama Executive Action on Immigration Expands DACA, Defers Deportation for Undocumented Parents, LATIN POST (Nov. 26, 2014), http://www.latinpost.com/ articles/26598/20141126/obama-executive-action-immigration-expands-daca-defers-deportationundocumented-parents.htm (stating that the protection lasts for three years and is then renewable).

6. Social Security Number and Card-Deferred Action for Childhood Arrivals, U.S. Soc. SECURITY ADMIN., available at http://www.socialsecurity.gov/pubs/deferred_action.pdf; see also American Immigration Council, Two Years and Counting: Assessing the Growing Power of DACA, AM. IMMIGR. COUNCIL (2014), available at http://www.immigrationpolicy.org/special-reports/twoyears-and-counting-assessing-growing-power-daca (noting that DACA "improves postsecondary access to education").

7. Due to a federal court injunction, Obama's executive action is now on hold, and there are indications that despite promises to the contrary, ICE is no longer following the Nov. $20^{\text {th }}$ deportation priorities. Consequently, how "life changing" this announcement really is, remains to be seen. Mathew Kolken, ICE No Longer Honoring Prosecutorial Discretion Memo, IWL.COM BLOGS (Feb. 26, 2015, 6:39 AM), http://blogs.ilw.com/entry.php?8490-ICE-No-Longer-Honoring-NewProsecutorial-Discretion-Memo.

8. Executive Actions on Immigration, U.S. CITIZENSHIP AND IMMIGRATION SERVICES (Feb. 17, 2015), http://www.uscis.gov/immigrationaction [hereinafter Executive Actions].

9. Id.; see also Obama Executive Order to Benefit at Least 5 Mn Undocumented, Fox NEWS LATINO (Nov. 20, 2014), http://atino.foxnews.com/latino/news/2014/11/20/obama-executiveorders-to-benefit-at-least-5-mn-undocumented/ (summarizing the effects of the executive orders announced on Nov. 20, 2014).

10. Politicians commonly argue whether DACA was responsible for this summer's immigration surge. A memo from the House Appropriations Committee included the statement that "[t]he dire situation on our Southern border has been exacerbated by the President's current immigration policies." Alex Nowraseth, DACA Did Not Cause the Surge in Unaccompanied Minors, CATO INST. (July 29, 2014), available at http://www.cato.org/blog/daca-did-not-causesurge-unaccompanied-children. However, there are also plenty of reasons to think this assumption is 
even assuming this link is real; the President's plan to decouple the two is not worth the cost. This article demonstrates that Obama's new immigration initiatives are responsible for the rising rates of family detention, the increased denial of credible asylum applications and a drastic retreat from the formerly generous interpretation afforded special immigrant juvenile status (SIJS). It then concludes that the benefits of expanding DACA do not justify jeopardizing the health and welfare of thousands of non-DACA eligible women and children.

\section{DACA, DREAMERS AND AMNESTY}

Immigration advocates often derisively refer to President Obama as "the deporter in chief." 11 This moniker is based on the fact that Obama has deported more immigrants than any other president. ${ }^{12}$ Nevertheless, despite the President's high rate of deportations, until recently, his deportation priorities focused on criminals rather than children and families. In fact, women and children were frequently the beneficiaries of many of the President's early immigration reforms. In 2009, in one of the first examples of the administration's de-emphasis on deporting women and children, President Obama ordered the closing of the Hutto family detention center in Texas and also set aside plans for the construction of three additional family detention centers. ${ }^{13}$ By closing these facilities, the President signaled his strong disapproval of family detention and indicated that the deportation of women and children was not a presidential priority. ${ }^{14}$

incorrect. First, the surge of unaccompanied minors began long before DACA was announced; second, the children who are coming are not eligible for DACA; and third, the unaccompanied children (UAC) are almost exclusive from Honduras, El Salvador and Guatemala despite the fact that children from other Central American countries would presumably be eligible for the same legal benefits. Id.

11. See, e.g., Donna Cassata, Head of NCLR Calls Obama "Deporter in Chief”, HufFInGTON Post LATINO VOICES (Mar. 5, 2014, 3:00 PM), http://www.huffingtonpost.com/2014/03/05/nclrdeporter-in-chief_n_4905811.html.

12. There is some debate on who should win this dubious title. This claim refers to the number of actual deportations that have taken place under Obama. After only six years in office, Obama has deported more than 2 million people while Bush deported less than that over his entire eight-year term. There is, however, some debate over this statistic since, while Obama has clearly deported more people, Bush oversaw more than 8 million informal returns. Returns do not carry the legal significance of deportation but they still remove people from the United States and many of these people do not return. See Nora Caplan-Bricker, Who's the Real Deporter-In-Chief: Bush or Obama, New RePUBLIC (Apr. 17, 2014), http://www.newrepublic.com/article/117412/deportations-underobama-vs-bush-who-deported-more-immigrants.

13. Nina Bernstein, U.S. to Reform Policy on Detention of Immigrants, N.Y. Times (Aug. 5, 2009), http://www.nytimes.com/2009/08/06/us/politics/06detain.html?pagewanted=all\&_r=0.

14. According to John Morton, head of Immigration Customs and Enforcement, the agency 
During his first term in office, Obama also began working to pass the Development, Relief, and Education for Alien Minors (DREAM) Act. ${ }^{15}$ The DREAM Act is a bill that, if passed, would provide a pathway to citizenship for undocumented immigrants who entered the country as children. The Act focuses on children, because children are typically seen as the group most "deserving" of U.S. citizenship and most able to take advantage of its benefits. The President's support of the DREAM Act was another indication of his promise to protect immigrant children and families and this commitment was further demonstrated by his decision to institute the Deferred Action for Childhood Arrivals (DACA) program.

President Obama proposed DACA in June 2012, after it had become clear that his efforts to pass the DREAM Act had been unsuccessful. The purpose of DACA was to achieve some of the DREAM Act's goals while avoiding the difficulty of obtaining congressional approval. DACA was successful. The President's deferred action program protected millions of children from deportation. ${ }^{16}$ However, the fact that the President circumvented Congress in order to create DACA resulted in a swift backlash. Republicans were livid the President had acted without their approval and in 2013, the House voted to defund DACA. ${ }^{17}$ By this

was taking a new approach to detention, "that the system's purpose was to remove immigration violators from the country, not imprison them, and that under the government's civil authority, detention is aimed at those who pose a serious risk of flight or danger to the community." Id.

15. See, e.g., President Obama on the Dream Act: "My Administration Will Not Give Up", The White House Blog (Dec. 18, 2010, 12:53 PM), http://www.whitehouse.gov/blog /2010/12/18/president-obama-dream-act-my-administration-will-not-give (after the Senate's failure to pass the DREAM Act, the President issued the following statement:

In an incredibly disappointing vote today, a minority of Senators prevented the Senate from doing what most Americans understand is best for the country. As I said last week, when the House passed the DREAM Act, it is not only the right thing to do for talented young people who seek to serve a country they know as their own, it is the right thing for the United States of America. Our nation is enriched by their talents and would benefit from the success of their efforts. The DREAM Act is important to our economic competitiveness, military readiness, and law enforcement efforts. And as the nonpartisan Congressional Budget Office reported, the DREAM Act would cut the deficit by $\$ 2.2$ billion over the next 10 years. There was simply no reason not to pass this important legislation. It is disappointing that common sense did not prevail today. But my administration will not give up on the DREAM Act, or on the important business of fixing our broken immigration system. The American people deserve a serious debate on immigration, and it's time to take the polarizing rhetoric off our national stage.).

16. Elise Foley, House Approves Another Steve King Immigration Amendment, HUFFINGTON POST (May 29, 2014), http://www.huffingtonpost.com/2014/05/29/steve-king-immigration _n_5412856.html.

17. The House Republicans passed a bill to defund DACA but, with a Democratic controlled Senate, it was clear the vote was largely symbolic. See id. Moreover, their rage was nothing compared to the outcry that occurred when the President suggested he would expand DACA in response to the border surge. 
point, it was clear that further DACA expansions would be met with even greater hostility. Nevertheless, in the summer of 2014, the growing border crisis and Congressional inaction convinced the President to consider expanding DACA. ${ }^{18}$

\section{A. The Legality of DACA}

Only Congress has the power to change the criteria for citizenship, and DACA was instituted without Congressional approval. Still, this does not make DACA unconstitutional. Deferred action is only a temporary reprieve from deportation. ${ }^{19}$ It does not change the rules for granting green cards or citizenship. Instead, it simply reflects the administration's deportation priorities. The President only created DACA because he could not legally enact the DREAM Act. ${ }^{20}$ While the DREAM Act would have provided undocumented immigrants with a permanent pathway to citizenship, all DACA does is give recipients a temporary reprieve from the possibility of deportation. ${ }^{21}$

The legality of DACA is also supported by significant Supreme Court case law, confirming the President's broad prosecutorial discretion over immigration matters. In its landmark decision Arizona v. United States, ${ }^{22}$ the Court emphasized this important role of the executive stating, "Federal officials, as an initial matter, must decide whether it makes sense to pursue removal at all." 23 The Court further noted that although "aliens may be removed if they were inadmissible at the time of entry," such removal is discretionary, not mandatory. ${ }^{24}$ Thirdly, the legality of the President's deferred action policy is also bolstered by the fact, as many scholars have noted, that setting formal criteria regarding deportation actually makes the process more consistent with the rule of

18. Athena Jones, Immigration Question: How Far Can the President Go on Executive Actions?, CNN (Aug. 7, 2014, 10:50 PM), http://www.cnn.com/2014/08/07/politics/obamaexecutive-actions/.

19. Consideration of Deferred Action for Childhood Arrivals Process: Frequently Asked Questions, U.S. CitiZENShIP AND IMMigRATION SERVICES, (Oct. 23, 2014), http://www.uscis. gov/humanitarian/consideration-deferred-action-childhood-arrivals-process/frequently-askedquestions.

20. Simeon Lancaster, As 'Dreamers' Renew Status, They Face Both Opportunities and Fears, MinNPost (Oct. 2, 2014), https://www.minnpost.com/politics-policy/2014/10/dreamers-renewstatus-they-face-both-opportunities-and-fears.

21. Frequently Asked Questions: The Obama Administration's Deferred Action for Childhood Arrivals (DACA), NATIONAL IMMigration LAW CENTER (Jan. 23, 2015), http://www.nilc. org/FAQdeferredactionyouth.html.

22. 132 S. Ct. 2492 (2012).

23. Id. at 2499 .

24. Id. 
law. Executive action regarding deportation priorities provides uniformity and predictability and prevents discrimination. ${ }^{25}$ If the guidelines for who gets deported and when deportation occurs are clear, then it is much harder for a government official to illegally target someone based on race or ethnicity. ${ }^{26}$ DACA actually increases the fairness and legality of deportation because it prevents these decisions from being affected by the biases of individual immigration agents.

\section{B. The Surge Connection}

Despite these legal justifications, many immigration opponents still view DACA as an unconstitutional exercise of presidential power. ${ }^{27}$ Consequently, it was not surprising that as soon as the President suggested expanding DACA, opponents of immigration reform were outraged. $^{28}$ In August 2014, the House voted to eviscerate DACA and

25. See generally Hiroshi Motomura, The President's Discretion, Immigration Enforcement \& The Rule of Law, AMERICAN IMMigration COUNCIL 5 (Aug. 2014), http://www.immigration policy.org/sites/default/files/docs/the_presidents_discretion_immigration_enforcement_and_the_rule _of_law_final_1.pdf (explaining the President's executorial discretion in enforcing immigration law and granting immigration relief ); see also Letter from Immigration Law Scholars and Professors (Nov. 25, 2014), available at https://pennstatelaw.psu.edu/sites/default/files/documents/pdfs/ Immigrants/executive-action-law-prof-letter.pdf (arguing that DACA helps "assure that important policy decisions are made at the leadership level, help[s] officers to implement policy decisions fairly and consistently, and offer[s] the public the transparency that government priority decisions require in a democracy"); Shoba Sivaprasad Wadhia, Sharing Secrets: Examining Deferred Action and Transparency in Immigration Law, 10 U. N.H. L. Rev. 1 (2012) (also providing a proposal for designing deferred action procedures). Geoffrey R. Stone, a law professor at the University of Chicago, also argued that the effect of "executive actions is to secure greater transparency by having enforcement policies articulated explicitly by high-level officials, including the President. Immigration officials and officers in the field are provided with clear guidance while also being allowed a degree of flexibility. This kind of transparency promotes the values underlying the rule of law." Geoffery R. Stone, Are the President's Actions on Immigration Legal?, HuFfington Post (Nov. 21, 2014, 10:24 AM), http://www.huffingtonpost.com/geoffrey-r-stone/are-the-presidentsaction_b_6198972.html.

26. Stone, supra note 25 .

27. Currently, Obama's executive action is on hold due to an injunction issued by a federal court judge in Texas in response to a lawsuit filed by DACA opponents. Bill Chappell, Federal Judge Blocks Obama's Executive Actions on Immigration, NPR (Feb. 17, 2015, 7:26 AM), http://www.npr.org/sections/thetwo-way/2015/02/17/386905806/federal-judge-blocks-obama-sexecutive-actions-on-immigration; see also, Kristen Williamson, Are President Obama's Actions Illegal?, IMMIGRATIONREFORM (Dec. 6, 2013), http://immigrationreform.com/2013/12/06/are-pres ident-obamas-actions-illegal/.

28. See, e.g., Joseph Weber, 'Wrong Side of the Constitution'? Obama Likely to Delay Deportations, Say Experts, Fox News (July 2, 2014), http://www.foxnews.com/politics/2014/07/ $02 /$ wrong-side-constitution-obama-likely-to-delay-deportations-say-experts/ ("Obama argues he has been compelled to act in large part because of the recent surge in unaccompanied Central American children showing up by the thousands at the U.S.-Mexico border and the GOP-controlled House's unwillingness to vote on the issue until at least after the November elections."); see also John Sexton, Timeline: Border Surge Began a Few Months After Obama's First Executive Action on 
prevent the President from creating a similar program for any new undocumented immigrants. ${ }^{29}$ A few weeks later, the Senate joined this opposition and proposed a bill to block DACA expansion and shortly thereafter, every Republican, as well as four Democratic senators, approved this bill. ${ }^{30}$ Then, two days after the Senate vote, all 22 Republican members of the house judiciary sent a letter to the White House demanding a full accounting of "the anticipated executive actions [Obama] will take to further dismantle our nation's immigration laws" and adding that whether it is now or in November, "it is never acceptable for the Executive Branch to ignore the Constitution and unilaterally give amnesty to unlawful immigrants." 31

The political opposition to DACA was unsurprising, but after the summer's immigration surge, public opposition also increased dramatically. ${ }^{32}$ People began worrying that the border children had been lured to the United States to take advantage of DACA, as well as other forms of immigration relief, and opponents of immigration reform stoked these fears. For example, Fox News' Fox \& Friends co-host Steve

Immigration, BREITBART (Aug. 5, 2014), http:/www.breitbart.com/blog/2014/08/05/timelineborder-surge-began-a-few-months-after-obama-s-first-executive-action-on-immigration/ (worrying about the impact of the President's proposed DACA expansion); Mark Noferi, The President's Solid Ground for Executive Action on Immigration, AM. IMMIGR. CounCIL (Aug. 26, 2014), http://immigrationimpact.com/2014/08/26/the-presidents-solid-ground-for-executive-action-onimmigration/ (noting that Obama was accused of "rewriting the law" and becoming "a domestic Caesar").

29. The House bill would have prevented the President from enrolling new applicants in the DACA program and it would have also stopped current DACA recipients from reapplying under the program. In addition, it would create a ban on funding any new DACA-like programs for any class of unlawful immigrant or providing such immigrants with any work authorization. See Jake Sherman \& Seung Min Kim, Border Battle House GOP Moves to Block Barack Obama, POLITICO (July 30, 2014), http://www.politico.com/story/2014/07/immigration-barack-obama-republicans109563_Page2.html; see also Elise Foley, Marco Rubio: End Relief for Dreamers, HuFFINGTON PosT (July 24, 2014, 8:30 PM), http://www.allsides.com/news/2014-07-25-1104/marco-rubio-endrelief-dreamers; Emma Dumain, Republicans Vote to End DACA After Tense Floor Debate, RoLL CALL (Aug. 1, 2014, 9:58 PM), http://blogs.rollcall.com/218/republicans-vote-to-end-daca/?dcz=.

30. Esther Yu-His Lee, Every Senate Republican Votes to Stop Obama's Immigration Relief, THINKPRogess (Sept. 19, 2014, 11:55 AM), http://thinkprogress.org/immigration/2014/09/19/ 3569204/senate-republicans-tone-deaf-daca-vote/.

31. Emma Dumain, Republicans to Obama: Show Us How You'll Change Immigration Law, RolL CALL (Sept. 22, 2014, 6:54 PM), http://blogs.rollcall.com/218/immigration-reform-repub licans-obama-change-laws/.

32. During the Kentucky Senate race, Mitch McConnell (rarely considered a bastion of liberalism) was attacked by his Democratic opponent for supporting amnesty back in 1986, the last time it was even on the table. The fact that since then he has routinely has voted against in-state tuition, educational benefits and other health care services for undocumented immigrants was still not enough to insulate him from anti-immigrant attacks. See, e.g., Mitch McConnell (R-KY) U.S. Senate Supports Amnesty for Illegal Aliens, AMERICANS FOR LEGAL IMMIGRATION PAC (Sept. 30, 2014, 9:57 PM), http://www.alipac.us/f34/mitch-mcconnell-r-ky-us-senate-supports-amnesty-illegalaliens-311783/. 
Doocy claimed Obama's lax immigration policies encourage children to cross the border illegally, and he insisted that "because the way the law is right now, if somebody who is a child asks to come across, for the most part they give them a pass." ${ }^{\text {"3 }}$ Similarly, Fox News' America's Newsroom co-host Bill Hemmer asserted the President was doing nothing about the border situation and contributor David Webb agreed, blaming the Obama administration for exacerbating "a human crisis" by "actively promoting" their "open borders approach." 34 Immigration opponents also specifically focused on DACA and argued that expanding DACA would exacerbate the problem of undocumented immigration. For example, conservative pundit Sean Hannity warned: "If Congress agrees to fund implementation of Obama's new executive amnesty, it will encourage more illegals-children $A N D$ adults - to take the dangerous route across the border. That's just wrong." 35

Obama expanded DACA despite this fierce opposition but he was not immune to these concerns. None of the new DACA beneficiaries are recent arrivals and it seems clear that the contours of the President's immigration reforms were intended to address and refute the accusation that DACA expansion will increase undocumented immigration. Consequently, in order limit DACA eligibility, the President drew a sharp line, January 1, 2010 to be precise, between recent immigrants and older arrivals. ${ }^{36}$ In addition, he also announced a new policy aimed at deterring further "illegal" immigration. Three aspects of this new deterrence policy are particularly concerning. First, it relies on family detention. Second, it creates obstacles to successful asylum claims and, third, it calls into question many of the formerly lenient aspects of Special Immigrant Juvenile Status. As a result of these policy changes, women and children are now the country's number one deportation priority.

\section{SHIFTING IMMIGRATION PRIORITIES}

One of the early hallmarks of Obama's immigration policy was a focus on criminal immigrants. This emphasis on deporting criminals was

\footnotetext{
33. Olivia Kittel, Fox News Uses Recent Surge in Child Migrants to Attack Obama's Immigration Policy, Media MATTERS FOR AMERICA (June 17, 2014, 4:07 PM), http://media matters.org/blog/2014/06/17/fox-news-uses-recent-surge-in-child-migrants-to/199760.

35. Sign the National Petition to End the Border Crisis Now!, Free State Patriot (Nov. 22, 2014), http://freestatepatriot.com/category/border-crisi-petition/.

36. See Executive Actions, supra note 8.
} 
exemplified by a program known as "secure communities," which began under President George W. Bush, but was greatly expanded under President Obama. ${ }^{37}$ The program used electronic matching of fingerprints to identify criminal aliens among those who were arrested nationwide. Then, identification detainers, known as Immigration and Customs Enforcement (ICE) holds, would be filed to keep the arrested alien imprisoned until ICE was able to take them into custody. ${ }^{38}$ The program was highly controversial and in November 2014, while announcing the expansion of DACA, Obama also declared the Secure Communities Program would be dismantled and that ICE officers will no longer be allowed to request holds. ${ }^{39}$

\section{A. Crimmigration}

The biggest problem with the Secure Communities program was that it often ensnared low-level violators. For instance, ICE holds for traffic violations were common. However, much more concerning was the fact that the program frequently affected poor parents struggling to provide for their kids. In one particularly disturbing example, an undocumented mother was placed in removal proceedings after she was picked up for shoplifting diapers and milk. ${ }^{40}$ It was these types of violations that the President was referring to when he announced the end of the Secure Communities program and promised that future deportations would focus on "[f]elons, not families. Criminals, not children. Gang members, not a

37. Suzanne Gamboa, Obama Ends Secure Communities Program That Helped Hike Deportations, NBC NEWS (Nov. 21, 2014), http://www.nbcnews.com/storyline/immigrationreform/obama-ends-secure-communities-program-helped-hike-deportations-n253541.

38. One of the pre-summer pressures facing ICE officers was the fact that many states were no longer complying with ICE detention requests. Thus, when an undocumented immigrant was picked up by state authorities they would increasingly refuse to honor the requests to hold them for ICE. This was problematic for ICE because for the past few years, this has been one of the primary ways ICE finds deportable immigrants and complies with the President's mandate to prioritize criminals over other undocumented immigrants. Consequently, the end of the Secure Communities Program may actually make the prioritization of criminals harder to achieve. Cindy Carcamo, More Jails Refuse to Hold Inmates, L.A. TimES (Oct. 4, 2014, 7:54 PM), http://touch.latimes.com/\#section/$1 /$ article/p2p-81589184/.

39. They are now simply allowed to ask to be notified of the alien's release date. According to a memo released by Department of Homeland Security Secretary Jeh Johnson, the reason for the change was that "the program has attracted a great deal of criticism, is widely misunderstood and embroiled in litigation; its very name has become a symbol for general hostility toward the enforcement of our immigration laws." Kate Linthicum, Obama Ends Secure Communities Program as Part of Immigration Action, L.A. TIMES (Nov 21, 2014, 6:00 AM), http://touch.latimes.com/\#section/-1/article/p2p-82045751/.

40. Christie Thompson, Deporting 'Felons Not Families', The Marshall Project, (Nov. 11, 2014, 5:22 PM), https://www.themarshallproject.org/2014/11/21/deporting-felons-not-families. 
mom who's working hard to provide for her kids. We'll prioritize, just like law enforcement does every day." 41

The move away from deporting mothers and breaking up families is not new. In 2006 a number of high profile workplace raids highlighted the problems caused by detaining immigrant parents. ${ }^{42}$ Nursing mothers were kept from their infants, children were placed in foster care, and many parents were deported without their children. ${ }^{43}$ Unsurprisingly, these actions caused outrage and in response, DHS instituted a number of policies to keep undocumented families together. One of the most important of these initiatives was a DHS directive stating that primary caretaker parents picked up by immigration authorities were to be released to care for their children whenever possible. Specifically, the directive informed ICE officers that they were to screen and identify individuals that might have caregiver issues at the time of arrest and that they were to conduct this screening in English and Spanish, orally and in writing, to "ensure that any alien with caregiver issues is not detained for any extensive period of time." 44 The directive also stated that if detention was necessary, it was supposed to occur in the facility nearest the detainee's children and that parental detainees were to be afforded

41. President Barack Obama, Remarks in Address to the Nation on Immigration (Nov. 20, 2014), available at http://www.whitehouse.gov/the-press-office/2014/11/20/remarks-presidentaddress-nation-immigration.

42. The Greely and Grand Island raids took place in 2006, the New Bedford Raid in 2007 and the Postville Iowa raid in 2008. Nancy Lofholm, Fear from Swift Plant Raid Resonates in Greeley Six Years Later, THE DENVER PosT (Jan. 15, 2013, 12:01 AM), http://www.denverpost.com/ci_223 74170/fear-from-swift-plant-raid-resonates-greeley-six (describing the Greely raid); Grand Island Police Refuse to Help With Raid, KETV (Dec. 12, 2006, 5:18 AM), http://www.ketv.com/GrandIsland-Police-Refuse-To-Help-With-Raid/10229186 (describing Grant Island raid); Monica Rhor, AP Impact: Immigration Raids Split Families, Boston Globe (Mar. 11, 2007), http://www.boston.com/news/local/massachusetts/articles/2007/03/11/ap_impact_immigration_raids split_families/?page=3 (describing New Bedford raid); Kourtney Liepelt, Impact of Postville Raid Lingers for Guatemalan Town, THE DES MOINES REGISTER (July 7, 2014, 1:22 AM), http://www.desmoinesregister.com/story/news/2014/07/07/effect-postville-raid-lingers-guatemalantown/12279567/ (describing Postville raid).

43. Randy Capps, et al., Paying the Price: the Impact of Immigration Raids on AMERICA'S CHILDREN, NATIONAL COUNCIL OF LA RAZA 30-40 (2007) (discussing the impact of immigration raids on children), available at http://www.urban.org/uploadedPDF/411566_immig ration_raids.pdf.

44. Letter from Susan M. Cullen, Dir., Office of Policy, Immigration Customs Enforcement, to Leslye E. Orloff, Dir., Immigrant Women Program, Legal Momentum (Feb. 7, 2008), available at http://niwaplibrary.wcl.american.edu/reference/additional-materials/immigration/enforcementdetention-and-criminal-justice/government-documents/Nursng-Mothers-and-Primary-CaretakerLetter-to-L-Mo.pdf/view; see also, USCIS Directive 11064.1 Facilitating Parental Interests in the Course of Civil Immigration Enforcement Activities (Aug. 23, 2013) (establishing "ICE policy and procedures to address the placement, monitoring, accommodation, and removal of certain alien parents."), available at $\mathrm{http} / / / \mathrm{www} . \mathrm{ice} . g o v / \mathrm{doclib} / \mathrm{detention-reform} / \mathrm{pdf} /$ parental_interest_directive signed.pdf. 
accommodations to meet their family reunification plans. In addition, a special provision was directed at nursing mothers and stated "that absent any statutory detention requirement or concerns such as national security, threats to public safety or other investigative interests, ICE agents should consider the conditional release of nursing mothers pending the results of their immigration removal hearings." 45

When President Obama took office he continued these policies. A 2011 DHS directive stated that:

Absent extraordinary circumstances or the requirements of mandatory detention, field office directors should not expend detention resources on aliens who are known to be suffering from serious physical or mental illness, or who are disabled, elderly, pregnant, or nursing, or demonstrate that they are primary caretakers of children or an infirm person, or whose detention is otherwise not in the public interest. ${ }^{46}$

By ending the Secure Communities program, the President signaled his intention to continue reforming immigration policy in ways that protect immigrant families. Similarly, DACA expansion was also presented as part of this promise to focus on "felons, not families."47 Nevertheless, the President's immigration policy is not nearly as protective of immigrant families as his Nov. 20th promise implies. Both DACA expansion and the end of the Secure Communities program primarily benefit undocumented immigrants already in the United States, particularly those who have been long-term residents. ${ }^{48}$ These reforms do not apply to recent arrivals and more worryingly; they actually reduce the protections available to these immigrants. ${ }^{49}$

\section{B. Detention}

In order to ensure DACA expansion would not incentivize undocumented immigration, the President instituted a policy of deterrence. Together, the Department of Homeland Security (DHS) and

\footnotetext{
45. $I d$.

46. See Memorandum from John Morton, Dir., Immigration Customs Enforcement, to All Immigration Customs Enforcement Employees, Civil Immigration Enforcement: Priorities for the Apprehension, Detention, and Removal of Aliens (Mar. 2, 2011) (emphasis added), available at http://www.ice.gov/doclib/news/releases/2011/110302washingtondc.pdf.

47. Executive Actions, supra note 8.

48. See, e.g., Aura Bogada, Goodbye Secure Communities. Hello, Priority Enforcement Program, COLORLINES (Nov. 21, 2014, 8:57 PM) (noting the "alarming similarities between SComm and PEP-Comm" and predicting that "the same thing will happen"), http://colorlines.com /archives/2014/11/goodbye_secure_communities_hello_priority_enforcement_program.html.

49. Id.
} 
the State Department developed policies intended to ensure that the majority of new, undocumented arrivals are detained and quickly deported. ${ }^{50}$ According to DHS Secretary Jeh Johnson, detention sends "a message that our border is not open to illegal migration, and if you come here, you should not expect to simply be released." "[T] "[This is an effective deterrent" said Johnson. ${ }^{52}$ However, one major concern with this new deterrence policy is that, since the majority of arriving undocumented immigrants are women and children, it requires the revival of family detention. ${ }^{53}$

Over the summer, the administration reversed its previous promise not to detain families and began rebuilding and expanding family detention centers. $^{54}$ In fact, in December 2014, the country's largest family detention center was opened in Dilley, Texas. ${ }^{55}$ The facility can hold up to 2,400 immigrants and was specifically designed for women and children. ${ }^{56}$ Secretary Johnson explained that the purpose of such facilities is to make a "sharp distinction between past and future." such statements make clear, under the President's new immigration reforms, long-term undocumented immigrants will be "forgiven," but recent and future arrivals will be detained and deported. ${ }^{58}$

\section{Bond}

Detention as deterrence is constitutionally problematic. Although the Supreme Court has consistently permitted the federal government to take actions against immigrants that would be impermissible against

50. According to Homeland officials, it is necessary to "dispel potential misinformation" about who is eligible for DACA or any other immigration relief. See Stephen Dinan, Feds Say Illegals Who Aid Others in Crossing Won't be Eligible for Amnesty, Washington Times (Jan. 5, 2015), $\mathrm{http}: / /$ www.washingtontimes.com/news/2015/jan/5/feds-say-illegals-who-aid-others-crossing-wontbe- $/$.

51. Johnson noted that many of the women in the Artesia family detention center stated "they did not expect to be detained if they made it to the United States." Julia Preston, Detention Center Presented as Deterrent to Border Crossings, N.Y. TIMES (Dec. 15, 2014), http://www.nytimes .com/2014/12/16/us/homeland-security-chief-opens-largest-immigration-detention-center-in-us.html.

52. $I d$.

53. Ian Gordon, Inside Obama's Family Deportation Mill, MOTHER JONES (Dec. 19, 2014, 6:15 AM), http://www.motherjones.com/politics/2014/12/family-detention-artesia-dilley-immigrat ion-central-america.

54. Id.

55. Id.

56. Id.

57. Preston, supra note 51.

58. Id. 
citizens, ordinary due process protections still apply. ${ }^{59}$ Detention is only acceptable when there is an individualized showing of need for such detentions, ${ }^{60}$ and punitive detention is always prohibited. ${ }^{61}$ In Zadvydas v. Davis, ${ }^{6}$ Justice Kennedy wrote "both removable and inadmissible aliens are entitled to be free from detention that is arbitrary or capricious. Where detention is incident to removal, the detention cannot be justified as punishment nor can the confinement or its conditions be designed in order to punish." 63 These concerns are even greater in the context of family detention because such detention affects children who are particularly vulnerable to harms relating to confinement. ${ }^{64}$ However, although the Zadvydas Court clearly held that detention cannot be used as a punishment, it did state that detention can be used to alleviate safety concerns. ${ }^{65}$ For this reason, the government has attempted to defend its family detention policy by arguing that every Central American family, including mothers and children fleeing violence, is a national security

59. See, e.g., Torao Takahashi v. Fish \& Game Comm'n, 334 U.S. 410, 419 (1948) ("The Federal Government has broad constitutional powers in determining what aliens shall be admitted to the United States, the period they may remain, regulation of their conduct before naturalization, and the terms and conditions of their naturalization.").

60. David Cole, In Aid of Removal: Due Process Limitations on Immigrant Detention, 51 EMORY L.J. 1003, 1007 (2002). Consequently, "immigration detention is not exceptional, but rather a form of civil detention subject to the same due process rules that apply to civil detention elsewhere." Id. at 1010. The Supreme Court has stated that immigration detention is only constitutional where the immigrant either poses a flight risk or a danger to the community. Zadvydas v. Davis, 533 U.S. 678, 721 (2001).

61. Nicole Flatow, ACLU Says Immigrants Are Being Indiscriminately Held in Detention As a Deterrent, THINK PROGRESS (Dec. 17, 2014, 9:18 AM), http://thinkprogress.org/justice/ 2014/12/17/3604323/aclu-says-immigrants-are-being-indiscriminately-held-in-detention-as-adeterrent/.

62. Zadvydas, 533 U.S. at 721.

63. Id.

64. Detention is mentally and physically damaging for children, especially ones who have already been victimized. Richard Cowan, U.S. Senators Blast Obama's Migrant Family Detentions, REUTERS (Oct. 17, 2014), http://www.reuters.com/article/2014/10/17/us-usa-immigration-congressidUSKCN0I61VF20141017 (Senate Majority Leader Harry Reid and Senate Judiciary Committee Chairman Patrick Leahy warning that it could be damaging to the young children housed there).

65. Zadvydas, 533 U.S. at 724-25. It can also be used to address flight risk but there are other methods of addressing flight risk, and regardless, a hearing is needed to determine whether such risks actually exist. "DHS already spends about \$2 billion in taxpayer resources annually on immigration detention - the sole purpose of which is to make sure people show up at court hearings. Alternatives to detention (ATD) are far less costly than institutional detention. In fact, family detention costs $\$ 266$ per person per day, whereas existing ATD programs cost 17 cents to $\$ 17.78$ per person per day. Alternatives are also effective. ICE's current ATD program has very high compliance rates-99 percent of enrollees appear at all court hearings and 84 percent comply with removal orders.” Press Release, Women's Refugee Commission, NGOs in Opposition to Family Detention in Dilley, Karnes, and Artesia. Letter to President Obama (Sept. 25, 2014), available at http://www.womensrefugeecommission.org/news/57-news-media-a-press/press-releases/2156-ngosunited-in-opposition-to-family-detention-in-dilley-karnes-and-artesia. 
risk. $^{66}$ In support of this position, the government cites a 2003 administrative decision (In re $D-J-$ ), issued by then-Attorney General John Ashcroft, which denied bond to a group of Haitian immigrants based on national security concerns. ${ }^{67}$ In In re $D-J-$, the Attorney General concluded that releasing Mr. D-J- during the "national emergency" created by the September 11 terrorist attacks would "give rise to adverse consequences for national security" and would "encourage further surges in illegal immigration [from Haiti] by sea." 68

Such national security arguments are inapplicable to the Central American women and children arriving at the U.S.-Mexican border. ${ }^{69}$ Nevertheless, most Immigration Judges are accepting these claims and routinely denying bond or setting it at absurd levels that detainees cannot pay. ${ }^{70}$ For instance, it is not uncommon for both a mother and her child to be required to pay 20 thousand dollars or more before they can be released from detention. ${ }^{71}$ In addition, in the rare cases when the Immigration Judge does grant bond for mothers and children, DHS is now appealing these rulings. ${ }^{72}$ Responding to this "blanket no release

66. See In re D-J-, 23 I. \& N. Dec. 572, 572 (A.G. 2003) (finding that "the respondent failed to demonstrate adequately that he does not present a risk of flight if released and should be denied bond on that basis as well").

67. Id.

68. Id. at 577, 579. His decision was based in part on the terrorist attacks of September 11, 2001, and on a State Department declaration that third-country nationals (including Palestinians and Pakistanis) were allegedly using Haiti as a staging point to enter the United States. Careen Shannon, Detaining Families Seeking Asylum is Just Wrong, THE HiLl (Dec. 19, 2014, 11:30 AM), http://thehill.com/blogs/congress-blog/civil-rights/227590-detaining-families-seeking-asylum-isjust-wrong.

69. Shannon, supra note 68. Many of these women are seeking asylum, and until this summer, such applicants simply needed to present a credible fear of persecution.

70. See, e.g., Immigrants Detained in New Mexico Seek Asylum and Boston Home, (Sept. 29, 2014), http://www.wbur.org/2014/09/29/immigrants-detained-in-new-mexico-seek-asylum-and-bost on-home (noting that " $[t]$ he national bond is $\$ 5,200$, and the problem we're having in Artesia, and what shocked me the most, is that bonds are being set for these women and children at $\$ 30,000$.").

71. Press Release, Am. Immigration Lawyers Ass'n, Stop the Obama Administration from Denying Bond to All Mothers and Children from Central America (Sept. 22, 2014), available at http://www.aila.org/infonet/ailas-take-on-bond-for-detained-families ("One of my clients today asked me to arrange for her deportation. She was breastfeeding and said that her son will not consume anything at the facility and is sustained entirely on breast milk. He is constantly sick. She had her bond hearing and the Judge set a $\$ 20,000$ bond for her and another $\$ 20,000$ for the $11 / 2$ year old").

72. Gayla Ruffer \& Lory Rosenberg, Back to the Dark Ages? The Imminent Danger of a Regional Domino Effect in Obama's Hardline Policy for Mothers Fleeing Central America, HUFFINGTON POST (Oct. 6, 2014, 1:06 PM), http://www.huffingtonpost.com/galya-ruffer/back-tothe-dark-ages-the_b_5923690.html ("How now to tell those same mothers and children, whose joy and relief could be heard over the phone after they were safely reunited with family, that the government was now appealing the bond decision ....”); see also Press Release, Am. Immigration Lawyers Ass'n, Administration Trying to Drag Mothers and Children Back to Detention (Sept. 23, 
policy,"73 the American Civil Liberties Union (ACLU) filed a lawsuit claiming that the categorical detention of mothers and children is not needed as a public safety measure and is unconstitutional. ${ }^{74}$ On February 20, 2015, a federal judge agreed with these arguments and ordered the Obama administration to stop detaining migrants solely "for the purpose of deterring future immigration." 75 As a result, immigration authorities will now have to look at the individual cases of the arriving mothers and children, but it remains to be seen how many detainees will actually be released.

\section{Asylum}

Descriptions of life in the family detention centers are heart wrenching. Half of the children booked in these centers during the summer were six or younger, infants were forbidden from crawling, and many of the children lost weight and became depressed. ${ }^{76}$ At the Karnes City family detention facility, there were reports of sexual abuse, extortion, and harassment by the guards. ${ }^{77}$ In addition, the lack of childcare meant mothers had to bring their children with them when they met with immigration attorneys to share their stories of violence and sexual assault. ${ }^{78}$ Not surprisingly, many of the mothers censored these stories to shield their children and hurt their asylum claims in the process. ${ }^{79}$ Moreover, this was not the only way detention hurt many immigrants' asylum claims. As ACLU lawyer Michel Tan has noted, "detention puts a whole lot of pressure on extremely vulnerable people to give up their cases.... The immigration authorities know that one way to facilitate removal is to keep people locked up." ${ }^{\prime 0}$ Tan and other

2014), available at http://www.aila.org/advo-media/press-releases/2014/admin-dragging-motherschildren-back-to-detention.

73. They argue that the failure to allow the release of immigrants who have established a "credible fear of persecution" is unconstitutional. On December 16, 2014, the ACLU filed a lawsuit specifically on the ground that "depriv[ing] families with bona fide asylum claims of their liberty in order to send a message to others is not appropriate." Shannon, supra note 68.

74. Id.; see supra Ruffer \& Rosenberg, note 72; John Burnett, Immigrant Advocates Challenge the Ways Mothers Are Detained, KQED News (Oct. 15, 2014, 2:20 PM), http://www.kqed.org/ news/story/2014/10/15/145413/immigrant_advocates_challenge_the_way_mothers_are_detained.

75. Julia Preston, Judge Orders Stop to Detention of Families at Borders, N.Y. TimeS (Feb. 20, 2015), http://www.nytimes.com/2015/02/21/us/judge-orders-stop-to-detention-of-families-at-borde rs.html?_r=0.

76. Gordon, supra note 53 .

77. $I d$.

78. $I d$.

79. Id.

80. Id. 
immigrant advocates believe that family detention is being used not only to deter, but to actively prevent immigrants from exercising their right to asylum. ${ }^{81}$

The number of detainees seeking asylum is high. In one Texas facility, asylum seekers made up 98 percent of the detainees. ${ }^{82}$ Under U.S. law, undocumented immigrants are eligible for asylum if they can show that they are unable or unwilling to return to their country "because of persecution or a well-founded fear of persecution on account of race, religion, nationality, membership in a particular social group, or political opinion." 83 Many of the detained immigrants meet this standard and with proper legal help they frequently receive asylum. ${ }^{84}$ The experience of women like Jessica Ramos, an immigrant placed in the Artesia family detention center with her two-year-old son, is typical. ${ }^{85}$ Ramos fled Honduras after her gang-affiliated boyfriend put a gun to her child's head and threatened to kill him and then her. ${ }^{86}$ According to Ramos, she had few options. The "law doesn't do anything there-what options do we have?"87 After arriving in the United States, Ramos spent months in detention but when she was finally able to obtain legal representation she was quickly found eligible for asylum and released. ${ }^{88}$

Ramos was lucky. Detention increases the difficulties of obtaining legal representation and a growing number of immigrants are being deported without ever seeing a lawyer. ${ }^{89}$ Undocumented immigrants

82. $I d$.

83. 8 U.S.C. $§ 1101(a)(42)(A)(2014)$.

84. In a survey of unaccompanied minors conducted by the United Nations High Commissioner for Refugees, 48 percent of the children interviewed said they were fleeing violence from armed criminals like drug cartels and gangs. Statistics on the high murder rates in many of the Central American countries confirm that much of this violence is targeted at young people, and it is responsible for the increased immigration of minors from these countries. This same report also showed that there has been a 712 percent increase in asylum claims from Central American nationals in other Central American countries. Alex Nowraseth, Family Reunification and Other Explanations for the Border surge of Unaccompanied Children, CATO INST. (June 25, 2014, 3:45 PM), http://www.cato.org/blog/family-reunification-other-explanations-border-surge-unaccompaniedchildren.

85. Gordon, supra note 53.

86. Id.

87. $I d$.

88. Id. Similarly, of the 12 women represented by a group from the American Immigration Lawyers Association, everyone was granted asylum. Preston, supra note 51.

89. Most of the detainees are deported under a system known as "expedited removal," which involves a more streamlined process than regular Immigration and Nationality Act [hereinafter I.N.A.] Section 240 removal proceedings and is reserved for people apprehended at or near the border. See 8 U.S.C. $§ 1225(b)(1)(A)(i)$ (2014) (permitting certain persons who are seeking admission at the border to the United States to be expeditiously removed without a full I.N.A. 
have no right to paid legal representation and family detention centers often intentionally prevent detainees from receiving lawyers. ${ }^{90}$ When the Artesia detention center first opened, lawyers were actually barred from entering and this only changed after a group of attorneys obtained a court order from a Los Angeles federal judge permitting them access to the detainees. ${ }^{91}$ Then, even after these attorneys were finally allowed inside the facility, they experienced repeated difficulty contacting their clients, were locked out of hearings, and were routinely denied interviews. ${ }^{92}$ Moreover, even ignoring examples of direct obstruction, the sheer number of detainees and the remote locations of many of the facilities also severely hampers detainees' access to lawyers and their likelihood of receiving asylum. ${ }^{93}$ Without legal representation, even immigrants with strong asylum claims face a high likelihood of deportation. ${ }^{94}$ According to Crystal Williams, director of the American Immigration Lawyers Association, the difference in outcomes between those with legal representation and those without is not even comparable:

Now, what we are seeing quite honestly, is the people who are getting asylum and are getting bonded out of... Artesia, had the attorneys not been there, they would have been removed already. The[y] would be

Section 240 immigration judge hearing); 8 U.S.C. § 1225(b)(1)(A)(iii) (authorizing the Attorney General to apply expedited removal to certain inadmissible noncitizens located within the United States); 69 Fed. Reg. 48,877 (Aug. 11, 2004) (providing that the Attorney General will apply expedited removal to persons within the United States who are allegedly apprehended within 100 miles of the border and who are unable to demonstrate that they have been continuously physically present in the United States for the preceding 14-day period).

90. In August 2014, a number of immigrants' rights groups filed a complaint alleging due process rights violations at the Artesia detention facility because of this difficulty regarding legal representation. Gordon, supra note 533.

91. Kent Paterson, The Ongoing Fight Against Migrant Family Detentions, COUNTERPUnCH, (Jan. 4 2015), http://www.counterpunch.org/2015/01/02/the-ongoing-fight-against-migrant-familydetentions/.

92. The Editorial Board, Deported from the Middle of Nowhere, N.Y. Times (Aug. 25, 201), http://www.nytimes.com/2014/08/26/opinion/at-an-immigrant-detention-center-due-processdenied.html.

93. Lawyers representing the Artesia detainees came from all over the country but their ability to continue to mount this kind of volunteer effort is highly doubtful. Artesia is closing, and the new facility in Dilley is more centrally located, but it remains unclear how much the detainees' access to legal counsel is improved. Preston, supra note 51.

94. The new Dilley detention center may be better in that it will be equipped with better facilities including three formal immigration courtrooms in the facility. Nevertheless, finding lawyers for the detained immigrants remains a huge problem. The American Immigration Lawyers Association, which handled asylum claims in Artesia, says they do not have the ability to mount a similar volunteer effort in Dilley. Preston, supra note 51. 
back in their home countries and facing the danger they were running from. ${ }^{95}$

\section{E. Immigration Hearings}

Most detainees never see a lawyer, but many also never see a judge. Prior to 1996, the majority of immigrants facing deportation received immigration court hearings. ${ }^{96}$ Now, most do not. ${ }^{97}$ According to a recent ACLU report, 83 percent of 438,421 deportations in 2013 involved no hearing or review by a judge: "Under the current system, thousands of people are subject to the whim and mercy of immigration officers who are acting as prosecutor, judge and deporter," said Sarah Menta, ACLU researcher and author of the report on recent deportations. ${ }^{98}$ According to Menta, "These officers are not equipped with the legal knowledge and expertise to decide who has rights or valid claims to enter and live in the United States." Menta shows that the move away from hearings began before the summer's immigration crisis but the recent immigration surge, combined with the administration's new deterrence policy, virtually ensures this trend will continue. ${ }^{100}$ Detaining people and denying them lawyers and a fair hearing increases deportations and when other potential asylees see that women and children with valid asylum claims are routinely deported these potential immigrants will presumably have little incentive to undertake the dangerous journey to the United States themselves. Consequently, these obstacles help achieve the desired immigration deterrence.

Creating obstacles to effective asylum claims raises serious due process concerns ${ }^{101}$, but it also raises moral concerns. One of the most

95. Suzanne Gamboa, Demand Intensifies for Non-Profit Immigration Lawyers, NBC NEws (Dec. 14, 2014, 6:37 AM), http://www.nbcnews.com/storyline/immigration-reform/demandintensifies-nonprofit-immigration-lawyers-n267206.

96. Suzanne Gamboa, ACLU: Speedy Deportations Force Out Many Without Hearing, NBC NEws (Dec. 8, 2014, 10:58 AM), http://www.nbcnews.com/news/latino/aclu-speedy-deportationsforce-out-many-without-hearing-n262691.

97. See id.

98. Press Release, ACLU, Immigration Officers Ordering Illegal Deportations without Hearings, Finds ACLU (Dec. 4, 2014), https://www.aclu.org/immigrants-rights/immigrationofficers-ordering-illegal-deportations-without-hearings-finds-aclu.

99. Id.

100. Id.

101. Complaint, M.S.P.C. v. Johnson, No. 1:14-cv-01437 (D.D.C. Aug. 22, 2014) (claiming that the treatment of the detainees with regard to hearings and legal representation violated the due process clause of the Fifth Amendment as well as the asylum regulations of the Immigration and Nationality Act), available at $\mathrm{http} / / /$ americanimmigrationcouncil.org/sites/default/files/M.S.P.C.\% 
important goals of U.S. immigration law is to provide refuge for immigrants fleeing persecution. ${ }^{102}$ However, because the President's deterrence policy makes no distinction between asylum petitioners and other detainees (perhaps because so many of them are claiming asylum) it undermines this important goal. All arriving adults are detained, denied bond and quickly scheduled for deportation. ${ }^{103}$ As a result, many immigrants who have valid asylum claims and should be granted the right to remain in the United States are instead, sent back to their home countries to face the horrors they were trying to escape.

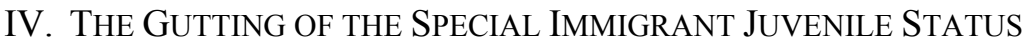

Potential asylees are not the only group seeing their rights threatened under the administration's new deterrence policy. Specifically, unaccompanied minors, a group that prior to this summer were commonly granted special immigrant juvenile (SIJ) status and the right to remain in the United States, are now also facing a significantly greater likelihood of deportation. ${ }^{104}$ More than half of the immigrants arriving at the border this summer were unaccompanied minors ${ }^{105}$ and under our current immigration law, many of these children are eligible for SIJ status. ${ }^{106}$ Nevertheless, the very fact that so many of these children potentially qualify for this form of immigration relief may ultimately doom their ability to receive it. Since the summer of 2014, there have been a number of changes, both formal and anecdotal, which threaten immigrant children's right to SIJ status protection.

20v.\%20Johnson.pdf.

102. United States asylum and refugee law was created after the horrors of World War II where, to the United States' lasting shame, a failure to offer asylum resulted in the murder of millions. See Asylum \& the Rights of Refugees, INT'L JUSTICE RESOURCE CTR., http://www.ijrcenter.org/refugeelaw/ (last visited May 25, 2015) (noting that "modern refugee law has its origins in the aftermath of World War II").

103. See American Exile: Rapid Deportations That Bypass the Courtroom, ACLU (Dec. 2014), https://www.aclu.org/sites/default/files/assets/120214-expeditedremoval_0.pdf. Hopefully, the recent injunction against blanket bond denials will change this.

104. David Nakamura \& Katie Zezima, Most Children Illegally Crossing the Border Alone Will Be Deported, White House Signals, WASHINGTON POST (July 7, 2014), http://www.washing tonpost.com/politics/most-children-illegally-crossing-the-border-alone-will-be-deported-whitehouse-signals/2014/07/07/0f9ec85e-0603-11e4-bbf1-cc51275e7f8f_story.html.

105. See U.S. Customs and Border Prot., U.S. DeP'T OF Homeland Sec., Southwest BORDER UNACCOMPANIED CHILDREN, available at http://www.cbp.gov/newsroom/stats/southwestborder-unaccompanied-children (last visited May 25, 2015) (listing the numbers of family unit apprehensions and unaccompanied minors).

106. William Wilberforce Trafficking Victims Protection Reauthorization Act of 2008, Pub. L. No. 110-457, § 235(d)(1)(A), 122 Stat. 5044, 5078-79 (2008) (setting out eligibility criteria). 


\section{A. The Rocket Docket}

Over the summer and in response to the flood of unaccompanied minors, the White House implemented a directive that unaccompanied minors must receive their hearing before an Immigration Judge within 21 days after ICE files a case against them. ${ }^{107}$ The problem, or benefit depending on your point of view, is that the faster a person is scheduled for deportation, the less likely it is that he or she will be able to make an effective claim for relief. Under U.S. law, children who arrive at the border alone are treated differently than other undocumented immigrants. Under the Trafficking Victims Protection Act (TVPA), these immigrant children are given shelter, ${ }^{108}$ allowed to remain in the custody of relatives while awaiting immigration hearings,${ }^{109}$ and have an automatic right to a hearing before a judge. ${ }^{110}$ In addition to these special protections, unaccompanied minors, until recently, were also an extremely low deportation priority. ${ }^{111}$ A combination of a massive immigration backlog and the Secure Communities program's emphasis on criminal offenders meant that unaccompanied minors could expect to remain in the United States a significant period of time before their immigration hearing and potential deportation. After the summer's surge, this all changed. Unaccompanied minors were suddenly placed at the head of the deportation line. ${ }^{112}$

Like the revival of family detention, the primary impetus behind these new, speedy deportations is the belief that quick deportations will discourage further Central American children from attempting to enter

107. Laila Hlass, Obama is Not Helping Children Who Face Deportation Alone, BostoN GLOBE (Oct. 26, 2014), http://www.bostonglobe.com/opinion/2014/10/25/obama-not-helpingchildren-who-face-deportation-alone/X0Z8Kn41eF9pS0aIRvMlTJ/story.html (noting that in Atlanta, the time to find a lawyer could be as little as nine days). However, it could have been even worse. One proposal the President considered, but did not ultimately adopt, was the possibility of seeking Congressional permission to treat the arriving Central American children like those from Mexico and Canada who can be sent back immediately without being housed and given full immigration proceedings. See Alan Gomes, Obama Seeks to Change Law That Protects Immigrant Kids, USA TODAY (July 2, 2014), http://www.usatoday.com/story/news/nation/2014/07/02/immigration-obamadeportation-children-border/11915723/.

108. See Olga Byrne \& Elise Miller, The Flow of Unaccompanied Children Through the Immigration System: A Resource for Practitioners, Policy Makers, and Researchers, CTR. ON IMMIGR. \& JUST. 10, 27 (Mar. 2012), available at http://www.vera.org/sites/default/files/resources/ downloads/the-flow-of-unaccompanied-children-through-the-immigration-system.pdf.

109. Id. at 4 .

110. 8 U.S.C. $\S 1232(a)(5)(D)(2012)$.

111. See Immigrants Left in Limbo After US Cancels Hearings as Some Fear Deportation, THE GUARDiAn (Feb. 1, 2015, 3:48 PM), http://www.theguardian.com/us-news/2015/feb/01/us-cancelsimmigration-hearings-thousands.

112. Id. 
the United States. ${ }^{113}$ Unfortunately, this change may also be causing the deportation of children who have a right to stay. A conservative estimate is that 60 percent of the border kids have credible claims for some kind of deportation relief. ${ }^{114}$ Nevertheless, fast deportations make it difficult to accurately identify children with credible claims. Twenty-one days is a short amount of time for these children to secure lawyers and it is not surprising that most fail to obtain legal representation. ${ }^{15}$ However, without lawyers few, if any of these children, can successfully navigate the intricacies of the immigration system.

Over the summer, newspaper accounts of the border crisis frequently mentioned the Kafkaesque sight of children as young as six, heads barely clearing the counsel table, representing themselves in immigration court. ${ }^{116}$ In some cases, judges have taken pity on these children, recognizing the harshness of the speedy deportation policy. On a recent day in a Los Angeles immigration court, 39 children were scheduled for one of these fast-tracked hearings but not a single one appeared. ${ }^{117}$ The children had been resettled outside of L.A. and had received letters on Saturday informing them they had to be in court on Monday. ${ }^{118}$ Although it would have been nearly impossible for any of them to appear given the large distance and short notice, the Immigration Judge still had the legal power to issue deportation orders. ${ }^{119}$ Fortunately, in that case, the judge, Ashley Tabaddor, did not issue deportation orders. ${ }^{120}$ Instead, she signed a change of venue order giving the children a chance to

113. Julia Preston, Obama to Seek Funds to Stem Border Crossings and Speed Deportations, N.Y. TIMES (June 28, 2014), http://www.nytimes.com/2014/06/29/us/obama-to-seek-funds-to-stemborder-crossings-and-speed-deportations.html?_r $=0$.

114. Patricia Zapor, Feds Grant \$4.2 Million in Funds for Legal Aid to Unaccompanied Minors, NAT'L CATHOLIC REPORTER (Oct. 3, 2014) http://ncronline.org/blogs/immigration-and-church/fedsgrant-42-million-funds-legal-aid-unaccompanied-minors.

115. "Ninety-four percent of children issued removal orders underwent their hearings without an attorney, the data said." Brianna Lee, 2014 Was the Year of the Child Immigrant Crisis and It May Reappear in 2015, INT'L BuS. TIMES (Dec. 27, 2014), http://www.ibtimes.com/2014-was-year-childimmigrant-crisis-it-may-reappear-2015-1765284.

116. See, e.g., Hlass, supra note 107; Kate Linthicum \& Molly Hennessy-Fiske, U.S. Sued for Not Providing Attorneys to Children in Immigration Court, L.A. TIMES (July 9, 2014), $\mathrm{http} / / / w w w . l a t i m e s . c o m / n a t i o n / n a t i o n n o w / l a-n a-n n-c h i l d r e n-i m m i g r a t i o n-c o u r t-20140709-$

story.html; Sandra Hernandez, Children Shouldn't Be Left Alone in Immigration Court, ACLU BLOG OF RIGHTS (July 9, 2014, 10:39 AM), https://www.aclu.org/blog/immigrants-rights-racialjustice/children-shouldnt-be-left-alone-immigration-court.

117. Katie Linthicum, Criticism Arises after Children Are Rushed to See Immigration Judges, L.A. TiMES (July 28, 2014), http://www.latimes.com/nation/la-na-immigration-courts-20140729story.html.

118. Id

119. Id.

120. Id 
appear at a later hearing before a judge closer to their location. ${ }^{121}$ Any other decision would have been reprehensible, but under the new deportation policy, it would have also been permissible.

\section{B. A Right to Counsel}

The fast-track docket also makes undocumented kids targets for exploitation. The large number of immigrant children seeking legal representation has created the opportunity for unsavory lawyers to take advantage of these children. For example, in a Daily Beast story on the border children, the reporter visited a New York City immigration court and noted that although most of the 37 kids in court that day said they had a lawyer, very few were accompanied by one, and it was clear the children had been scammed. ${ }^{122}$ The presiding judge, Virna Wright, explained to the children, "If he doesn't come, you don't have an attorney... If you are going to pay someone, they have to come to court ...."

An additional concern regarding legal representation for unaccompanied minors is the fact that even if these children are able to find an affordable lawyer, who legitimately wants to help, most of these lawyers are stretched so thin that their ability to provide effective counsel has become highly questionable. According to Claire Thomas, an attorney with the Safe Passage Project, one of a number of pro bono organizations that have stepped in to provide assistance to unaccompanied minors, the new caseload has become nearly impossible to handle. ${ }^{124}$ Thomas noted that "[b]efore we were managing about 30 cases a month, now we're getting 30 cases a day." 125 To cope with the increased caseload, many immigrant legal services groups like Safe Passage have had to enlist the help of pro bono attorneys who lack immigration backgrounds. ${ }^{126}$ In the past, these lawyers would have had about 60 days to prepare but now, they have no more than three weeks and frequently much less. ${ }^{127}$

121. Id.

122. Caitlin Dickson, The Border Kid Crisis Hits the Courts, The Daily Beast (Sept. 19, 2014), http://www.thedailybeast.com/articles/2014/09/19/the-border-kid-crisis-hits-the-courts.html.

123. Id. That article also noted the infuriating example of one woman who had paid a lawyer 500 dollars to fill out a two line change of address form.

124. Id.

125. Id.

126. Id.

127. Id. 
The President's speedy deportation policy makes it harder for children to find counsel and thus seems to contravene the Trafficking Victims Protection Act (TVPA), which states that the secretary of health and human services must ensure "to the greatest extent practicable" that all unaccompanied children have legal representation, and it encourages the U.S. Department of Health and Human Services (HHS) to "make every effort to utilize the services of pro bono counsel" to represent these children free of charge. ${ }^{128}$ Some civil rights groups are making even greater claims. In addition to seeking to enforce the protections of the TVPA, these immigration advocates argue that the government is constitutionally obligated to provide unaccompanied minors with lawyers. ${ }^{129}$ In July 2014, the ACLU filed a class action, J.E.F.M. v. Holder ${ }^{130}$ charging that it is a violation of the $5^{\text {th }}$ amendment not to provide the border children with federally funded lawyers. ${ }^{131}$ Shortly after the suit was filed, the President announced plans to distribute $\$ 1.8$ million (through Justice AmeriCorps) in grants to legal organizations that represent unaccompanied minors and to distribute another $\$ 9$ million through HHS to help fund immigration services for children facing deportation. ${ }^{132}$

The funds promised by the President are vastly insufficient to address the problem of unrepresented minors, ${ }^{133}$ yet even these minimal

128. William Wilberforce Trafficking Victims Protection Reauthorization Act of 2008, Pub. L. No. 110-457 § 235(c)(5), 122 Stat. 5044, 5079 (2008); 8 U.S.C. § 1232(c)(5) (2006). Relatedly, in January 2014 the Fiscal Year 2014 Omnibus appropriations bill included language to "improve unaccompanied children's access to legal services and child advocates." Megan Hatcher-Mays, No Civil Rights for Them: Right-Wing Media Don't Think Unaccompanied Minors Deserve Lawyers, Media MATTERS For AMERICA Blog (Oct. 1, 2014, 3:49 PM), http://mediamatters.org/blog/ 2014/10/01/no-civil-rights-for-them-right-wing-media-dont/200972.

129. Elise Foley, San Francisco Supervisors Vote to Provide Lawyers for Kids Facing Deportation, HUFFINGTON POST (Sept. 17, 2014), http://www.huffingtonpost.com/2014/09/17/sanfrancisco-immigrants_n_5836230.html.

130. Complaint, J.E.F.M. v. Holder, No. 2:14-cv-01026, (W.D. Wash. July 9, 2014), available at https://www.aclu.org/sites/default/files/assets/filed_complaint_0.pdf.

131. Id.

132. Michael Lindenberger, U.S. to Spend \$9 Million to Find Lawyers for Unaccompanied Minors in Nine Cities, Including Dallas, Trail Blazers Blog, Dallas Morning News (Sept. 30, 2014, 3:18 PM), http://trailblazersblog.dallasnews.com/2014/09/u-s-to-spend-9-million-to-findlawyers-for-unaccompanied-minors-in-9-cities-including-dallas.html/.

133. Reformers argue that the President could use executive action to provide lawyers for these children but there is no indication the President is considering that. See, e.g., Michael Matza, Debate Continues Over Young Immigrants Right to Counsel, PHILly.COM (Dec. 3, 2014), http://articles.philly.com/2014-12-03/news/56653449_1_juvenile-cases-young-immigrantstransactional-records-access-clearinghouse (noting the that the "ACLU's campaign calls on President Obama to go beyond his recent use of executive power to require free legal counsel for all children in deportation hearings"). 
funding attempts were met with fierce opposition. ${ }^{134}$ Opponents argued that such funding was "legally dubious" and an "illegitimate use of taxpayer dollars" and they specifically pointed to a provision in the Trafficking Victims Protection Act (TVPA), which states that any representation of unaccompanied minors must be "at no expense to the government."135 Since this backlash, there has been little talk of additional funding and it seems likely that many children with valid claims for immigration relief will not get the legal assistance they need to avoid deportation.

\section{Dependency Actions}

Legal representation for unaccompanied minors is crucially important because under the TVPA, immigrant children who are judged abused or abandoned and become wards of the state are entitled to permanent residency. ${ }^{136}$ The legal term for this form of immigration relief is called "Special Immigrant Juvenile Status" (SIJS) and until this summer, Immigration Courts had been applying the requirements for SIJ status fairly liberally. However, there are increasing indications that, after the border surge and in light of the government's new deterrence policy, this leniency is rapidly evaporating. ${ }^{137}$ One such example of this trend concerns the treatment of state dependency orders.

In SIJS cases, immigration and family law are closely intertwined and before a child can receive SIJ status, there must first be an order of dependency issued by a state family court declaring the child abused or neglected and dependent on the state. ${ }^{138}$ In the past, there was great

134. Before this summer, such a move might have gone mostly unchallenged. For example, in January 2014 the Fiscal Year 2014 Omnibus appropriations bill passed, which included language to improve unaccompanied children's access to legal services and child advocates. Consequently, there appeared to be a recognition that simply relying on pro bono lawyers to assist them was not sufficient. However, bipartisan support for such assistance has now disappeared. See HatcherMays, supra note 128.

135. 8 U.S.C. $§ 1232(c)(5)$ (2012); see also Immigration Reform News and Impact on U.S. Homeland Security, RIGHT SIDE NEwS (Oct. 14, 2014), http://www.rightsidenews.com/ 2014120935241/us/homeland-security/immigration-reform-news-and-impact-on-us-homelandsecurity-december-9-2014.html; Miriam Jordan, U.S. Government To Provide 9 Million in Legal Aid to Child Migrants, WALL ST. J. (Sept. 30, 2014), http://www.wsj.com/articles/u-s-government-toprovide-9-million-for-legal-aid-to-child-migrants-1412106221 ("House Judiciary Committee Chairman Bob Goodlatte (R., Va.) said that providing 'taxpayer-funded lawyers' to migrants would encourage more illegal immigration.").

136. Ctr. for Pub. Policy Studies, Special Immigrant Juvenile (SiJ) Status (2013), available at $\mathrm{http}: / / \mathrm{www}$. sji.gov/PDF/Special\%20Immigrant\%20Juvenile\%204-1-13.pdf.

137. See infra Part IV.

138. 8 U.S.C. $§ 1101(a)(27)(J)(i)(2014)$. 
deference to state court dependency determinations, but that may be changing. On October 8, 2014, the American Immigration Lawyers Association (AILA) asked its members to send in examples of SIJS cases where U.S. Citizenship and Immigration Services (USCIS) questioned the state dependency order. ${ }^{139}$ The call for examples suggests that USCIS may now be making their own determinations regarding whether an immigrant child is truly dependent and that this will result in the increased deportation of older unaccompanied minors.

It is likely the majority of cases in which USCIS is second guessing state dependency orders relate to the age of the unaccompanied minor. In order to be SIJS eligible, the child must be under 21 and unmarried at the time he or she is first declared a juvenile court dependent. ${ }^{140}$ Historically, the difficulty has been that many states do not allow the family court to find someone over 18 a dependent. ${ }^{141}$ In these states, 18 year-olds are barred from accessing state juvenile courts and this can prevent them from securing the necessary findings for a SIJS petition. ${ }^{142}$ As a result, children who are under 21 but over 18 face significant hurdles demonstrating their eligibility for SIJ status. ${ }^{143}$ A 2010 resource manual published by the Immigrant Legal Resource Center highlighted this problem stating:

"[A]s far as CIS is concerned, a 19-year-old could become a juvenile court dependent for the first time at age 19 and could file an SIJS petition and have it approved - so long as he or she meets the other SIJS requirements. In reality however, this would be very difficult to achieve. Most jurisdictions will not declare a youth dependent once they are 18 or older. In fact, advocates report significant difficulties in obtaining juvenile court jurisdiction even for older children who are close to their 18th birthdays."

139. Call for Examples: SIJS Cases Where USCIS Questions the Dependency Order, AILA8: Today's Top Immigr. Items (Am. Immigration Lawyers Ass'n., Washington, D.C.) Oct. 8, 2014 (on file with author) ("The AILA USCIS Field Operations Liaison Committee requests Special Immigrant Juvenile Status (SIJS) case examples in which USCIS is re-adjudicating or questioning the dependency order issued by the State Court in an RFE, NOID, and/or denial.").

140. 8 U.S.C. $\S 1101(a)(15)(T)(i i)(2014)$.

141. Heryka Knoespel, Special Immigrant Juvenile Status: A "Juvenile" Here Is Not a “Juvenile” There, 19 WASH. \& LEE J. CIV. RTS. \& SOC. Just. 505, 513 (2013).

142. Id.

143. Some states, such as Florida, which normally release jurisdiction at 18 , have made exceptions for non-citizens and permit courts to retain jurisdiction past the normal 18 year-old cut off if the child petitions to extend jurisdiction until their SIJ petition is considered. Id. at 522 .

144. Immigrant Legal Res. CtR., SPeCial IMmigrant JuVEnile Status For ChildREN AND YOUTH UNDER JUVENILE COURT JURISDICTION 3-8 (2010), available at http://www.ilrc.org/ files/2010_sijs-chapter_03-sijs_overview.pdf [hereinafter IMMIGRANT LEGAL]. 
Such statements show that until recently, the difficulty with dependency orders was the unwillingness of state courts to issue orders for immigrant children over the age of 18 , as opposed to an unwillingness on the part of USCIS to accept such orders. ${ }^{145}$ Now, this leniency on the part of USCIS appears to be changing. The AILA request suggests that immigrant children between the ages of $18-21$, the age of many of this summer's recent arrivals, are beginning to have their state dependency orders questioned by USCIS. SIJS specifically applies to children up to age 21, but the summer's immigration crisis appears to have encouraged USCIS to start trying to limit SIJS applications to children under 18.

\section{One or Both Parents}

Limiting SIJS eligibility to children under 18 would drastically reduce the number of immigrant children protected from deportation and it is possible that such motivations will spur USCIS and other immigration authorities to limit children's eligibility for SIJS in other ways as well. One potentially devastating change would be to limit SIJS to only those immigrant children who can show abuse or neglect by both parents. Currently, most courts hold that in order to be SIJS eligible, an immigrant child is only required to demonstrate that reunification with one parent is not viable. ${ }^{146}$ These courts have held that as long as an immigrant child is declared dependent due to the abuse or neglect of one parent, they may be eligible for SIJ status regardless of the fact that reunification with the other parent is possible. ${ }^{147}$ Originally, SIJS kids needed to show reunification with both parents was not viable ${ }^{148}$ but this requirement was changed in the Trafficking Victims Protection Reauthorization Act of 2008 (TVPRA), which states that a child is eligible for SIJS if "reunification with 1 or both ... parents is not viable due to abuse, abandonment, neglect, or a similar basis. ..."149 After this revision, the majority of state courts read this provision to mean that a child is eligible for SIJS as long as there are abuse allegations against

145. See Human Rights Initiative, Special Immigrant Juvenile Status (Family Law PORTION) 5 (2008), available at http://www.hrionline.org/wp-content/uploads/2012/09/Ch-22Special-Immigrant-Juvenile-Status-Family-Law-Portion.pdf.

146. 8 U.S.C. $\S 1101(a)(27)(J)(i)(2014)$.

147. See, e.g., In re Karen C., 111 A.D.3d 622 (N.Y. App. Div. 2013); In re Welfare of D.A.M., No. A12-0427, 2012 WL 6097225 (Minn. Ct. App. Dec. 10, 2012).

148. See ImMigRAnt LegaL, supra note 144, at 3.

149. William Wilberforce Trafficking Victims Protection Reauthorization Act of 2008, Pub. L. No. 110-457 § 235(d)(1)(A), 122 Stat. 5044, 5079 (2008), INA 101(a)(27)(J). 
one parent, even if there is the possibility of reunification with another parent. ${ }^{150}$ These courts hold that a one-parent interpretation is consistent with the legislative history of the TVPRA, which expanded SIJS eligibility by specifically removing the Act's original "both parents" language. ${ }^{151}$

Recently, some courts have begun reaching a different conclusion. They interpret the TVPRA to require a finding that both parents have abused, abandoned, or neglected the child. For example, in In re Erick $M .,{ }^{152}$ the trial court denied the motion for SIJS findings based on the fact that although Erick had been removed from his mother's custody due to delinquency, she remained actively involved in his life, and reunification was anticipated. ${ }^{153}$ On appeal, Erick argued that the expected resumption of custody by his mother did not preclude a finding of SIJ status because his father had abandoned him and reunification with his father was not possible. ${ }^{154}$ Erick thus argued that he was still eligible for SIJS due to the non-viability of reunification with his father ${ }^{155}$ but the Nebraska Supreme Court rejected this argument. ${ }^{156}$ The Court held that the statutory language "one or both parents" is susceptible to more than one reasonable interpretation. ${ }^{157}$ It conceded that Erick's interpretation was reasonable but explained that the "one or both parents" provision could also mean that the court must find that "either reunification with one parent is not feasible or reunification with both parents is not viable." 158 In other words, the court believed that the child could have one parent for whom reunification is at issue or two parents for whom reunification is at issue, depending on who was involved in the child's life prior to removal. ${ }^{159}$ In this case, the court determined that both parents were at issue, and that Erick therefore had to demonstrate that reunification was not viable with either parent.

Two years later, a New Jersey appellate court decided H.S.P. v. $J . K{ }^{160}$ The court followed the Erick $M$. decision and determined that it

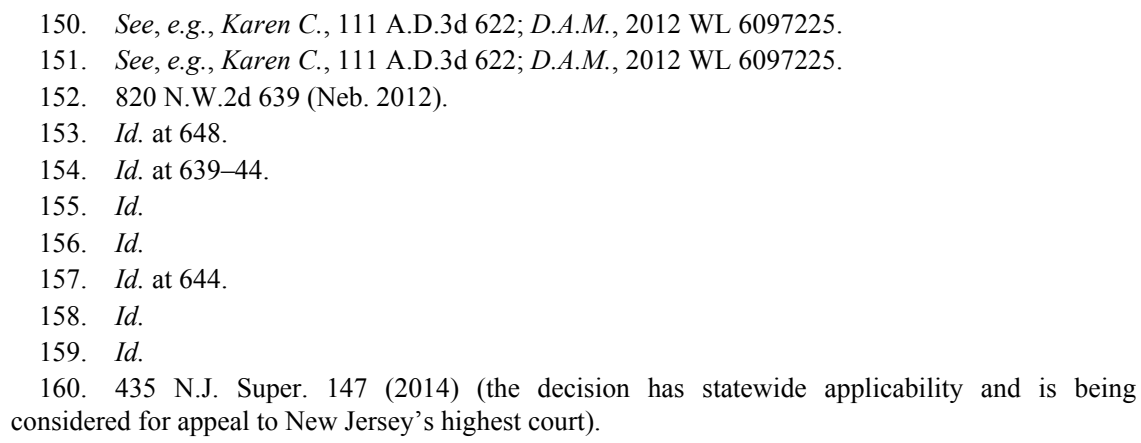


could not make the required SIJS finding without facts demonstrating that both parents were unavailable for reunification due to abuse, abandonment, or neglect. ${ }^{161}$ The court found that the child in question had demonstrated abandonment by his father, but that he had not been abused, abandoned, or neglected by his mother. ${ }^{162}$ The court also discussed the history and purpose of SIJS relief and determined that the child in H.S.P. was not the kind of child legislators had in mind when they decided to provide SIJS relief. ${ }^{163}$

Currently, Erick M. and H.S.P. are outlier cases but the President's deterrence policy and the push to deport the majority of recent arrivals may make these kinds of decisions increasingly common. Legislative history supports a more lenient interpretation of the "one or both parents" requirement. Nevertheless, the fact that many of the undocumented minors arriving at the border are coming to reunite with a parent in the United States may negatively impact their eligibility for SIJS. The country is already highly fearful of incentivizing additional undocumented immigration and it is more than likely that this concern will spur increasing numbers of courts to hold that SIJS is only available to children who have been abused or abandoned by both parents. ${ }^{164}$

\section{CONCLUSION}

President Obama's executive action may help millions of long term undocumented immigrants avoid deportation and create a permanent life in the United States. This is a laudable goal. Unfortunately, the cost of achieving this reform is too high. The President's decision to expand DACA goes hand in hand with new federal policies to increase the detention and deportation of recent undocumented immigrants. More disturbingly, these policies are directed at the most vulnerable immigrants, many of whom have a legal right to remain in the United States. True immigration reform would include these women and children, and until this occurs, all we have is the mirage of immigration reform.

\footnotetext{
161. Id. at 166 .

162. Id. at 159 .

163. Id. at $166-70$.

164. See Meghan Johnson \& Kele Stewart, Unequal Access to Special Immigrant Juvenile Status: State Court Adjudication of One-Parent Cases, AM. BAR Ass'N (July 14, 2014), http://apps.americanbar.org/litigation/committees/childrights/content/articles/summer2014-0714unequal-access-special-immigrant-juvenile-status-state-court-adjudication-one-parent-cases.html (noting that the Erik M. and H.S.P. courts "seem to have been improperly concerned about opening the floodgates of immigration relief to children abandoned by one parent").
} 